\title{
Promote Healthy Emotions in Your Child
}

\author{
Vidya Bhagat $^{1}$, Mainul Haque ${ }^{2 *}$, Rohayah Husain ${ }^{1}$ \\ ${ }^{1}$ Faculty of Medicine, Universiti Sultan Zainal Abidin, Medical Campus, Jalan Sultan Mahmud, Kuala Terengganu, Terengganu, \\ MALAYSIA. \\ ${ }^{2}$ Faculty of Medicine and Defence Health, Universiti Pertahanan Nasional Malaysia, (National Defence University of Malaysia), \\ Kem Perdana Sungai Besi-57000 Kuala Lumpur, MALAYSIA.
}

Received: 02 November 2019;

Accepted: 19 December 2019

*Correspondence to:

Mainul Haque,

Faculty of Medicine and Defence Health, Universiti Pertahanan Nasional Malaysia, (National Defence University of Malaysia), Kem Perdana Sungai Besi, 57000 Kuala Lumpur, MALAYSIA.

Email: runurono@gmail.com Copyright: (C) the author(s),publisher and licensee Indian Academy of Pharmacists. This is an open-access article distributed under the terms of the Creative Commons Attribution Non-Commercial License, which permits unrestricted non-commercial use, distribution, and reproduction in any medium, provided the original work is properly cited.

\begin{abstract}
Emotional development starts at an early age. This development is significant that it facilitates the children who are in preschool and assist their interaction with others. Indeed, emotional development expedites the overall development of children both in social and intellectual ways. This article aims at conceptualizing developmental mechanisms that promote healthy emotions in children. In a nutshell, views of this article indicate that fostering emotional health in children by using the knowledge about wellness that can shape your healthy life.
\end{abstract}

Key words: Encourage, Good, Physical, Mental, Silhouette, Feelings, Frame of mind, Youngster, Kid.
Emotional development and intellectual development typically go hand in hand and support a child's social development and emotional regulatory process. It is the interaction amongst children and adults that paves a way to a healthy emotional state. This psychological state is necessary for developing children when they react to their environment. The dynamic and functionalist thought concerning emotional development and regulation in childhood gives a blended view of a child's personality. ${ }^{[1]}$ This blend is seen in a child when it encounters an environment be active transactions that involve multiple emotion-related to functional aspects such as emotional behavior, physiological patterning, action tendencies, goals and motives, social and physical contexts, appraisals and experiential feeling. ${ }^{[1]}$ Further, these emotions get regulated over time with a child's maturity and response to the changing environment. Childs emotional development reflects their experiences of social and cultural context. This development takes a bioecological framework and dynamically interacts in community context. ${ }^{[2]}$ The difference between positive and negative feelings towards any given situation is commonly due to emotional regulation that takes place during the developmental stage. This emotional regulation works in its own way to promote emotional health. It has been learned from past literature that emotional health involves attending to and fine-tuning thoughts, feelings and behaviors.

Thus, trying to develop awareness and conceptualizing this fact is valued. Literature that found the fact that energy extended to gain knowledge of emotional health that can benefit from creating and maintaining well-being; thus, it is well worth the effort. ${ }^{[3]}$ Defining and living your emotional health leads to positive change and personal growth, a healthy sense of selfconfidence. ${ }^{[3]}$ Some children respond very well to a multitude of different social situations and interactions, which would suggest they have an emotional development that is resilient, whereas many other children who have undergone emotional traumas, those who endured ups and downs in their emotional experiences, may face emotional difficulties. Indeed, these children with emotional challenges have a negative impact on their social life and daily routine. Emotional development is significant since it promotes emotional regulation, coping behavior in children and assist the child in expressive conduct needed for productive interaction. Further, these behaviors will help the child in their relationship building. Emotional development and its mechanisms have been listed in the Table 1.

The emotional functioning is different in people depending on which they are adaptively and self-efficacy towards the goal achievement is acquired. Emotional competence needs different types of affect-oriented behaviors. During child development, these behaviors observed as emerging cognitive and regulatory skills; lather these skills are congruently used overtime in their social context. ${ }^{[4]}$ However, the capabilities of emotional competence are also influenced by past social experience and learning. Thus, enriching experiences in individuals in their relationships and social interactions can promote psychological health. As one of the research studies indicates that emotional health can lead to success in work, relationships and health. ${ }^{[5]}$ The past research revealed that success made people happy; but analysis of newer research reports indicated another way around that happy people are more likely to work toward goals, find the resources they need and attract others with their energy and optimism that has been understood as building blocks of success. ${ }^{[5]}$

The unfolding of emotional life depends on caregivers how they promote internalizing trust in the environment. Secure in his or her attachment to 


\begin{tabular}{|c|c|c|c|c|}
\hline \multirow[t]{2}{*}{ Age group } & \multirow[t]{2}{*}{ Developmental stage } & \multicolumn{3}{|l|}{ Mechanisms } \\
\hline & & Regulation & Expressive Behavior & Relationship Building \\
\hline $0-12$ months & Infancy & $\begin{array}{l}\text { Self- learning to modulate reactivity } \\
\text { Regulation of attention to coordinated } \\
\text { actions } \\
\text { Relying on caregivers for support in various } \\
\text { circumstances }\end{array}$ & $\begin{array}{l}\text { Behavior gets synchronized with others } \\
\text { through expressions } \\
\text { Learning to discrimination of others' } \\
\text { emotions } \\
\text { Increased expressive responsiveness in } \\
\text { situations with contingent control } \\
\text { Improved coordination of expressive } \\
\text { practices with emotion-eliciting } \\
\text { circumstances }\end{array}$ & $\begin{array}{l}\text { Learning social competitiveness } \\
\text { Getting new social orientations } \\
\text { Learning to use socially operational cues }\end{array}$ \\
\hline $\begin{array}{l}12 \text { months to } \\
2 \frac{1}{2} \text { years }\end{array}$ & Toddlerhood & $\begin{array}{l}\text { Develop self-awareness and } \\
\text { consciousness of their own emotional } \\
\text { response } \\
\text { Irritability offshoots due to constraints limits } \\
\text { imposed } \\
\text { Start touchiness about limitation expanding } \\
\text { autonomy towards exploration needs }\end{array}$ & $\begin{array}{l}\text { Self-evaluation and self-consciousness } \\
\text { become evident; there is an increase in } \\
\text { verbal comprehension and production } \\
\text { of words for expressive behavior and } \\
\text { affective states. }\end{array}$ & $\begin{array}{l}\text { Learning to anticipate different feelings } \\
\text { toward other people, } \\
\text { increasing discrimination of others' } \\
\text { emotions, a better understanding of the } \\
\text { underlying meaning of others emotional } \\
\text { expression, } \\
\text { footing early forms of empathy and pro- } \\
\text { social action }\end{array}$ \\
\hline $2-5$ years & Early childhood & $\begin{array}{l}\text { Using Symbols advances and facilitates } \\
\text { emotion regulation, } \\
\text { Yet time symbols can cause distress. } \\
\text { Communication with others extends } \\
\text { the child's evaluation towards their own } \\
\text { feelings, emotion-eliciting occasions and } \\
\text { consciousness into these aspects. }\end{array}$ & $\begin{array}{l}\text { Using and adoption of the false mask of } \\
\text { emotional behavior in play. } \\
\text { The rational understanding of false } \\
\text { facial expressions can mislead others } \\
\text { regarding one's feelings }\end{array}$ & $\begin{array}{l}\text { Generally, communication with others } \\
\text { elaborates on a child's knowledge of } \\
\text { social transactions. } \\
\text { Sympathetic and pro-social behavior } \\
\text { toward peers stems out } \\
\text { Insight increases regarding the emotions } \\
\text { of others. }\end{array}$ \\
\hline 5-7 years & Middle childhood & $\begin{array}{l}\text { The self-conscious about emotions are } \\
\text { targeted for regulation. } \\
\text { Still, they use a coping strategy that } \\
\text { taking support from caregiver's there is an } \\
\text { increase in reliance on problem-solving in } \\
\text { different situations }\end{array}$ & $\begin{array}{l}\text { Accepting and adopting an unruffled } \\
\text { emotional persona with peers. }\end{array}$ & $\begin{array}{l}\text { Coordination in social skills is increasing. } \\
\text { Better insight into one's own and others' } \\
\text { emotions } \\
\text { Understanding of consensual emotional } \\
\text { scripts in a relationship }\end{array}$ \\
\hline $7-10$ years & Late childhood & $\begin{array}{l}\text { Using strategic coping in problem-solving } \\
\text { They learn to discard coping strategies that } \\
\text { have no or minimal control over problem- } \\
\text { solving. }\end{array}$ & $\begin{array}{l}\text { Accepting social norms and learn to } \\
\text { express behavior accordingly. } \\
\text { They modulate dynamic relationships } \\
\text { using expressive behaviors. }\end{array}$ & $\begin{array}{l}\text { A spurt of various emotions toward the } \\
\text { same person. } \\
\text { They value friendships. Thus, they give } \\
\text { time for personal information about } \\
\text { another person that can aid in the } \\
\text { development of close friendships. }\end{array}$ \\
\hline $10-13$ years & Preadolescence & $\begin{array}{l}\text { Use accurate evaluation of their own ability } \\
\text { to control stressful situations. } \\
\text { Use alternative solutions and differentiate } \\
\text { strategies qualitatively to deal with stress. }\end{array}$ & $\begin{array}{l}\text { They learn to distinguish between } \\
\text { genuine and fabricated emotional } \\
\text { expression. } \\
\text { They learn how to use these emotional } \\
\text { expressions with close friends and } \\
\text { others. }\end{array}$ & $\begin{array}{l}\text { Individuals' social development makes } \\
\text { them socially sensitive; they are aware of } \\
\text { the emotional expressions that help them } \\
\text { to play their social roles aptly. }\end{array}$ \\
\hline 13 and above & Adolescence & $\begin{array}{l}\text { Regulating own emotional cycles facilitates } \\
\text { insightful coping. } \\
\text { Increasing integration of moral character } \\
\text { and personal philosophy in dealing with } \\
\text { stress and subsequent decisions }\end{array}$ & $\begin{array}{l}\text { Use of Skills embracing their own } \\
\text { demonstration strategies to get } \\
\text { appraisals and form impressions in their } \\
\text { environment. }\end{array}$ & $\begin{array}{l}\text { The consciousness is well maintained } \\
\text { regarding mutual and reciprocal } \\
\text { communication of emotions. } \\
\text { Carefulness about affecting the quality of } \\
\text { the relationship. }\end{array}$ \\
\hline
\end{tabular}

the caregiver and child relationship establishes the base for the development of emotional skills and paves the way for future social relations. These attachments open the door for a child to explore the world and engage with peers. Insecure attachment leads to emotional and social incompetence, particularly in the areas of emotion understanding and regulated anger emotion. ${ }^{[6]}$ The hostile social environment influences subsequent emotional responses such as anxiety or fear in their interpersonal transactions. ${ }^{[7]}$ The unhealthy behaviors such as aggressive or submissive displayed in children seeking self-protection, such practices as at risk for a bully victim in their later life. Cognitive-affective structures associated with abused child induce emotional constriction and interfere with a child's ability to engage successfully with peers. ${ }^{[8]}$

Thus, it is significant to develop positive emotions, as well as emotional competence in children, make them emotionally healthy. Indeed, this helps them to live their life comfortable and lesson problems. Healthy emotions in individuals equip them with emotional competency and environmental assets and smoothen their coping skills in situational issues. One of the literatures has revealed that Emotional health is steeped in positive characteristics, meaning that positive emotions are apposite in achieving emotional health. ${ }^{\left[{ }^{[9]}\right.}$ The description about emotionally healthiness given in Help Guide (2016) included some facts that are people as having a sense of contentment, a zest for life, the ability to deal with stress and obstacles, a sense of meaning and purpose in life, flexibility to learn and adapt, a balance between work and play, the ability to create and maintain relationships and self-confidence and high self-esteem. ${ }^{[10]}$ Positive psychologists believe that emotional health is more than just optimism; instead, it is an authentic understanding of what indeed makes us happier. ${ }^{[1]}$

Healthy emotions competence is the resource that helps people to face challenges. Promoting healthy emotions strengthens emotional expertise in children and adolescents enhance their coping skills. Also, it endorses the characteristics associated with positive developmental outcomes, including feelings of self-efficacy, pro-social behavior. Healthy emotions are also important that pave supportive relationships with family and other people. The past literature had learned that emotional competence in emotionally healthy person outspreads the skills related to reading interpersonal cues, solving problems, executing goal-oriented behavior in interpersonal 
situations. ${ }^{[12]}$ Psychological healthiness paves instrumental and affective responses.

\section{CONCLUSION}

Improving emotional health is like enhancing our physical health. Emotional health and well-being involve defining and creating our own lives worth living. Thus, the article elucidates some of the facts related to emotional health and mechanisms that promote healthy emotions during the developmental period. Therefore, a collection of these facts arranged in this article may help people in improving psychological health in their children that can pave an entrance to the healthy social system.

\section{ACKNOWLEDGEMENT}

Authors are much grateful to the Library authority of National Defence University of Malaysia and Universiti Sultan Zainal Abidin, Malaysia for the kind cooperation to provide necessary manuscript.

\section{CONFLICT OF INTEREST}

The authors possess no conflict of interest.

\section{ABBREVIATIONS}

None

\section{REFERENCES}

1. Saarni C, Campos J, Camras L, Witherington D. Principles of emotion and emotional competence. Child and Adolescent development: An Advanced Course. Wiley. 2008;23:361-405.
2. Saarni C. The interface of emotional development with social context. The Handbook of Emotions, $3^{\text {rd }}$ Edition, New York: Guilford Press. 2008;3:332-47.

3. Healthy Place. What is Emotional Health? And How to improve it?. 2017. Available at https://www.healthyplace.com/other-info/mental-illness-overview/what-isemotional-health-and-how-to-improve-it/

4. Saarni C. The development of emotional competence. New York: Guilford Press. 1999.

5. Lyubomirsky S, King L, Diener E. The benefits of frequent positive affect: Does happiness lead to success?. Psychol Bull. 2005;131(6):803-55.

6. Denham SA, Blair KA, DeMulder E, Levitas J, Sawyer K, Auerbach-Major S, Queenan P. Preschool emotional competence: Pathway to social competence. Child Dev. 2003;74(1):238-56.

7. Pollak SD, Cicchetti D, Hornung K, Reed A. Recognizing emotion in faces: Developmental effects of child abuse and neglect. Dev Psychol. 2000;36(5):67988.

8. Pollack SD. Mechanisms linking early experience and the emergence of emotions: Illustrations from the study of maltreated children. Curr Dir Psychol Sci. 2008;17(6):370-5.

9. Positive Psychology Program. What is Emotional Health and what it is not: Body and Brain. 2016. Available at https://positivepsychologyprogram.com/emotionalhealth-definition-mike-oppland/

10. Smith M, Segal R, Robinson L, Segal J. Building Better Mental Health 6 LifeChanging Strategies to Boost Mood, Build Resilience and Increase Happiness. Help Guide Org. 2018. Available at https://www.helpguide.org/articles/mentalhealth/building-better-mental-health.htm?pdf=true [April 8, 2018]

11. Van KGA. How Emotions Regulate Social Life. The Emotions as Social Information (EASI) Model. Curr Dir Psychol Sci. 2009;18(3):184-8.

12. Shields A, Dickstein S, Seifer R, Guisti L, Magee KD, Spritz B. Emotional competence and early school adjustment: A study of preschoolers at risk. Early Education and Development. 2001;12(1):73-96.

Cite this article as: Bhagat V, Haque M, Husain R. Promote Healthy Emotions in Your Child. J Pharm Pract Community Med. 2019;5(4):60-2. 